\title{
Chapter 11 \\ Fertility Ideals of Women and Men Across the Life Course
}

\author{
Anne-Kristin Kuhnt, Michaela Kreyenfeld, and Heike Trappe
}

\subsection{Introduction}

"Ich möchte niemals Kinder sind für mich das Größte" ("I do not want children are the most important thing to me") was a slogan of the insurance company Swiss Life in 2015. The slogan ridicules the volatility of people's preferences regarding children and family life. Having children may evolve from being a subordinate issue to being the focal point of attention in a person's life. In our paper, we explore the volatility of women's and men's fertility ideals across time. In particular, we examine how fertility ideals evolve as people age, how patterns differ by gender, and whether other factors - such as changes in an individual's partnership or employment domain-lead to changes in fertility ideals. Our study contributes to the large body of literature that has explored different concepts of fertility desires and intentions in Germany (e.g., Buhr and Kuhnt 2012; Heiland et al. 2008; Keim et al. 2009; Kuhnt 2013; Kuhnt and Trappe 2013; Lutz et al. 2013; Marbach and Tölke 2013; Rost 2005; Ruckdeschel 2007), for other countries (e.g., Bernardi et al. 2015; Iacovou and Tavares 2011; Klobas and Ajzen 2015; Liefbroer 2009; Miller 2011;

\footnotetext{
A.-K. Kuhnt $(\bowtie)$

Institute of Sociology, University of Duisburg-Essen, Duisburg, Germany

e-mail: anne-kristin.kuhnt@uni-due.de

M. Kreyenfeld

Hertie School of Governance, Berlin, Germany

Max Planck Institute for Demographic Research, Rostock, Germany

e-mail: kreyenfeld@hertie-school.org

H. Trappe

Institute of Sociology and Demographic Research, University of Rostock,

Rostock, Germany

e-mail: heike.trappe@uni-rostock.de
} 
Morgan 1982; Quesnel-Vallée and Morgan 2004; Spéder and Kapitány 2015; Thomson 1997; Thomson and Hoem 1998; Vignoli et al. 2013) or across countries (e.g., Balbo and Mills 2011; Kapitány and Spéder 2013; Philipov et al. 2006; Puur et al. 2008; Régnier-Loilier et al. 2011; Testa 2007; Testa and Basten 2014).

While there are a large number of studies on this issue, little research has been done on the stability of fertility preferences. Most of the existing literature on fertility preferences has focused either on short-term fertility intentions (e.g., Billari et al. 2009; Dommermuth et al. 2011; Goldstein et al. 2003; Gray et al. 2013; Hayford 2009) or on the extent to which fertility intentions are realised (e.g., Berrington and Pattaro 2014; Schoen et al. 1999; Spéder and Kapitány 2009, 2015; Toulemon and Testa 2005). In our study, we investigate how the fertility ideals of women and men in Germany of the cohorts 1971-73, 1981-83, and 1991-93 evolved over a 5-year period spanning 2008/2009-2013/2014. Thus, our study covers a longer time period than most previous research. Fertility preferences are measured using the following question: "Under ideal circumstances, how many children would you like to have?" The aim of this question is to survey personal fertility ideals, rather than societal family size ideals, which were, for example, surveyed in the Eurobarometer (Testa 2007). The concept of personal fertility ideals is also different from the concept of fertility intentions, which is usually measured by asking respondents about their concrete plans for having a child within a narrowly defined time frame of, for example, 2 years (Miller 2011; Thomson 2001). It is, however, related to the widely used concept of fertility desires, which is usually measured by asking respondents how many children they wish to have (Thomson 2001: 5347). Compared to fertility intentions, fertility desires or ideals are probably more stable across time (Miller 1994, 2011). This is particularly the case given the first part of our question: the qualifier "under ideal circumstances" prompts the respondents to disregard the current conditions. We test whether significant changes in a person's life, such as the loss of a job or of a partner, affect his or her fertility ideals. We also examine whether the birth of a child (or the lack thereof) leads a person to adjust his or her fertility goals upwards or downwards. Here we draw upon the psychological literature that shows that people tend to revise their long-term goals if they are unable to accomplish them. For the sake of readability, we use the terms "fertility ideals" and "fertility preferences" interchangeably. The paper is structured as follows. In Sect. 11.2, we provide the theoretical background and review prior research findings. In Sect. 11.3, we describe the data we use, which come from the German Family Panel (pairfam) and cover respondents of the birth cohorts 1971-73, 1981-83, and 1991-93. Furthermore, we present our method and analytical strategy in this section. In Sect. 11.4, we present our descriptive results. In Sect. 11.5 , we discuss our findings from the multivariate analyses, which consist of a pooled OLS regression and fixed-effects modelling. The dependent variable is the respondent's ideal number of children, and the main covariates are the respondent's partnership status, employment status, and number of children. In Sect. 11.6, we discuss the implications of our findings. 


\subsection{Theoretical Considerations and Prior Findings}

The life course has been described as a self-referential process within which an individual acts or behaves based on his or her prior experiences and resources (Mayer 2004). Values, convictions, and emotions are part of the internal opportunity structure that guides individual behaviour (Huinink and Feldhaus 2009). Fertility ideals can be seen as fundamental and quite general value orientations, or as expressions of family size norms (Iacovou and Tavares 2011; Thomson 2001). However, there is some debate among researchers about how stable such value orientations are across the life course. According to the socialisation hypothesis, convictions and values are formed in late childhood and adolescence, and remain relatively stable thereafter. These values can be viewed as the concepts and scripts that guide an individual's future life plans (Inglehart 1977), or as mere lifestyle preferences (Hakim 2003). Others have raised concern over the stability of preferences across the life course. A person's values measured at a given moment in time not only influences action, but that action affects attitudes, values, and aspirations. The only way researchers can separate the causal linkage between attitudes and behaviour is by using panel data (Lesthaeghe and Moors 2002).

An important behavioural model that is often employed in the study of fertility preferences is the model of reasoned action developed by Ajzen and Fishbein (Ajzen 1991; Fishbein and Ajzen 2010). This concept distinguishes between desires and intentions (e.g., Bühler 2012; Miller 2011; Thomson 2001). Desires are "internal factors", such as motivations, attitudes, and beliefs (Miller 1994: 228). If desires become more manifest, they materialise into intentions, which will in turn be translated into behaviour if conditions are favourable. In our study, we analyse "fertility ideals", which are not examined as a distinct category in the Ajzen and Fishbein model. While it is clear that ideals are not the same as intentions, it is important to note that although fertility ideals are related to fertility desires, ideals and desires are not identical. Thus, previous findings on the volatility of fertility intentions and fertility desires may not be transferable to the study of the volatility of fertility ideals. We assume that fertility ideals, as measured by the phrase in our survey question "under ideal circumstances", are more stable than intentions, because ideals do not depend on actual living conditions (Miller 2011). Thus, a change in partnership status or economic circumstances may lead to a change in fertility intentions, but not necessarily in fertility ideals. However, if the adaptation argument applies, we can assume that the individual's achieved biographical status will affect his or her fertility ideals, as a person's current circumstances rarely align with his or her initial ideal scenario. For example, a woman might increase her ideal number of children so that it corresponds with the number of children she already has. Miller and Pasta (1995) have suggested that the birth of a first child can trigger in the parent an increase in his or her positive motivations for childbearing, as there is a biological mechanism that enhances the parent's positive responses to the baby, and thus strengthens his or her desire to have another child. Fertility preferences may also be adjusted upwards if an individual has an unplanned birth, or if his or her children do 
not have the desired gender. These scholars have also posited that there are mechanisms that counterbalance this positive feedback loop, such as delays or negative motivations. Fertility ideals might be adjusted downwards if, for example, a woman who is growing older perceives that it is unlikely that her initial ideals will be fulfilled (Gray et al. 2013).

\subsubsection{Previous Findings}

Relatively few studies have examined the stability of fertility ideals, desires, or intentions. Of the studies on the evolution of fertility expectations that exist, the most comprehensive was conducted by Hayford (2009) for women in the US. Hayford's analysis of 10 years of panel data collected between 1979 and 1994 showed that women tend to have relatively stable fertility expectations across their life course. For Europe, longitudinal studies on the stability of fertility desires or intentions have been conducted for the United Kingdom, France, Germany, and the Netherlands (Buhr and Kuhnt 2012; Heiland et al. 2008; Iacovou and Tavares 2011; Liefbroer 2009; Ní Bhrolcháin and Beaujouan 2011; Ní Bhrolcháin et al. 2010). However, most of these studies covered only two survey waves, and thus did not examine the evolution of fertility preferences across a longer period of time. These studies also differed considerably in terms of the concepts they used to measure fertility preferences. For example, some used fertility desires, while others used fertility expectations or intentions in assessing the "ideal family size". Despite the many conceptual differences between these studies, the following commonalities emerge.

Demographic factors, and especially age, have been shown to influence the stability of fertility intentions across an individual's life course. Fertility preferences seem to decline with increasing age (Gray et al. 2013; Hayford 2009; Heiland et al. 2008; Ní Bhrolcháin et al. 2010). Buhr and Kuhnt (2012: 291) found for Germany that over a period of 1 year, women and men in their early thirties are more likely than women and men in their early twenties to adjust the number of children they expect to have. Using data from the Netherlands, Liefbroer (2009: 363) showed that among both women and men, there is a downward adjustment in fertility intentions with increasing age. Using British panel data, Ni Bhroichain et al. (2010: 14) and Iacovou and Tavares (2011: 119) found a similar pattern: i.e., that the expected family size declines with increasing age. An intervening variable in this context may be fecundity, which also declines over time. Individuals who realize that they are infecund may adjust their fertility preferences in recognition of their biological constraints (Heiland et al. 2008; Liefbroer 2009; Régnier-Loilier 2006).

There is also longitudinal evidence that having a child leads to changes in fertility preferences. Heiland et al. (2008: 150) found that the fertility expectations of parents increase after the birth of an additional child. Similarly, Iacovou and Tavares (2011: 119) found that having a child is associated with upward and downward revisions in fertility expectations. However, their findings did not indicate that the birth of a first child has a greater effect on expectations than a subsequent birth. 
There is also consistent evidence that changes in the partnership domain of the life course lead to changes in fertility preferences (Buhr and Kuhnt 2012; Iacovou and Tavares 2011; Spéder and Kapitány 2009). Buhr and Kuhnt (2012: 288) found considerable changes in the fertility intentions of men and women whose partnership situation had changed in the preceding year. Meanwhile, Hayford (2009: 777) found that married women have more stable fertility expectations than women who are single. Similarly, Heiland et al. (2008: 148) found that divorce or separation has a negative effect on the stability of the number of desired children among women. The findings of Iacovou and Tavares (2011: 119) indicate that having no partner or being separated from a partner is associated with a downward revision of fertility expectations across time.

Other studies have explored how changes in the employment domain of the life course relate to changes in fertility preferences. Heiland et al. (2008: 147) reported that unemployment has a negative, but insignificant effect on changes in the desired number of children. Buhr and Kuhnt (2012: 290) were unable to produce any statistically significant results supporting the notion that changes in labour force status affect fertility expectations. Iacovou and Tavares (2011: 119) studied the effect of income on fertility preferences. Their results show that while a man's income is not correlated with changes in the expected number of children, if a woman has a high income she tends to adjust her expected number of children downwards.

In summary, fertility preferences seem to be quite sensitive to changes in partnership status, but less sensitive to changes in economic circumstances. However, the psychological literature tells us that people may adjust their long-term goals based on the likelihood that they will achieve them. We therefore assume that the birth of (further) children may lead individuals to adjust their fertility ideals upwards.

\subsection{Data and Analytical Strategy}

This study uses data from the first six waves (2008/09-2013/14) of the German Family Panel (pairfam) and its supplement DemoDiff, release 6.0 (Brüderl et al. 2015). The German Family Panel (pairfam) is a panel survey that provides data on the formation and development of intimate relationships and families in Germany (Brüderl et al. 2015; Huinink et al. 2011). DemoDiff is a survey of residents of eastern Germany that is designed to complement the German Family Panel (Kreyenfeld et al. 2012). The pairfam and DemoDiff interviews are conducted annually with individuals from eastern and western Germany of the cohorts 1971-73, 1981-83, and 1991-93. The total number of respondents in wave 1 was 13,891 . Overall attrition from wave 1 to wave 6 was about $46 \%$, which is within the normal range for panel studies in Germany with this duration (Müller and Castiglioni 2015). In our investigation, we have omitted respondents with invalid information on our key variables of interest, and especially those who failed to provide valid information on the ideal number of children or who said they were uncertain if they wanted children. The final sample includes 13,645 observations and 51,653 person-years of data. 


\subsubsection{Method \& Analytical Strategy}

The empirical analysis consists of two parts. In a first step, we provide descriptive statistics that depict the development of fertility preferences by age and gender. Moreover, we employ OLS-regression that examines the determinants of fertility preferences. The dependent variable is the reported fertility ideal. In order to account for the multiple observations of individuals in the sample, we calculate robust standard errors. Moreover, we employ fixed-effects modelling to gain a better understanding of the causal determinants of fertility preferences. The great advantage of using fixed-effects modelling is that it allows us to account for individual-specific time-constant heterogeneity (Allison 2009; Andreß et al. 2013; Schmidt 2013; Brüderl and Ludwig 2014). The drawback is that only characteristics that vary over time may be included in the analysis as covariates. Our main focus in the multivariate analysis is on the effects on fertility preferences of the respondents' employment status, partnership status, subjective financial situation, and number of children. A further control variable is the respondents' age. In the OLS-regression, we also include region, and migration status.

Our main variable of interest is the response to the fertility ideals measured by the following question: Under ideal circumstances, how many children would you like to have? The dependent variable has a mean of 2.2 and ranges from zero to seven children. ${ }^{1}$ Figure 11.1 shows that a majority of the respondents reported that they prefer to have two children. This finding is in line with those of previous studies on western Europe that showed that most people report that their ideal number of children is 2 (Goldstein et al. 2003; Testa 2007). The differences between women and men were minor: Men were more likely than women to say they prefer to have two children (men: $60 \%$; women: $55 \%$ ), while women were slightly more likely than men to say they prefer to have three or four children. Among both men and women, just six per cent reported that they see childlessness as the ideal (see Fig. 11.1).

The independent variables in our analysis are the respondent's age, partnership status, employment status, number of children, and subjective assessment of the financial situation of his or her household. Age is treated as a categorical variable broken down by the following age groups: 14-19, 20-29, 30-39, and 40-42. Partnership status is a dummy variable that distinguishes between being single and being in partnership, regardless of whether the respondent is living with the partner. We also control for the number of children, and distinguish between respondents who are childless, have one child, have two children, or have three or more children. Employment status is distinguished using the following categories: in education, full-time employment, part-time employment, unemployment, and other activities. The subjective assessment of the financial situation is an ordinal scaled variable that

\footnotetext{
${ }^{1} \mathrm{~A}$ few of the respondents in the initial data set reported an ideal number of children that was higher than seven. Since there were only a few such observations, and because they may have biased our analyses, we excluded them from our analytic sample.
} 

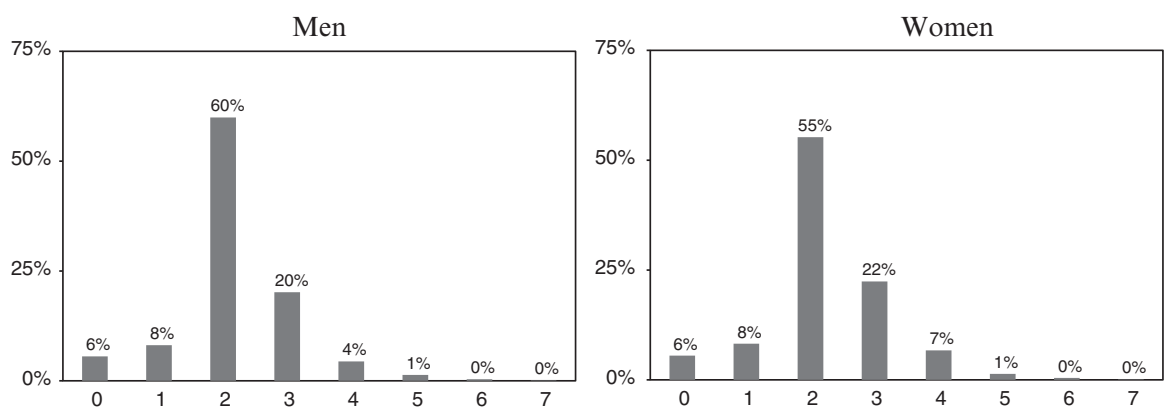

Fig. 11.1 Ideal number of children by gender (Source: German Family Panel (pairfam) wave 1-6, Release 6.0, weighted estimates)

ranges from zero (not satisfied) to 10 (absolutely satisfied). While unemployment is an objective variable used to measure economic conditions, the perception of financial satisfaction is a more subjective variable. In the OLS-regression, we also control for (largely) fixed covariates, such as region (eastern or western Germany), migration background (born in Germany or born in a different country), and level of education. In generating the level of education, we use the ISCED-97 classification to distinguish between respondents with low (ISCED 0-2), medium (ISCED 3-4), and high levels of education (ISCED 5-6). Table 11.1 reports the sample statistics.

\subsection{Descriptive Results}

In a first step, we analyse the mean ideal number of children by age for men and women (see Fig. 11.2). Please note that we do not yet exploit the within variation, and that the graphs in Fig. 11.2 merely give the mean values of fertility ideals by the age of the respondents. We have separated the graphs by birth cohorts and gender. Among men in their early twenties, the average ideal number of children is 2.1. These values increase modestly to 2.2 children over the life course. On the whole, however, the fertility ideals of men do not seem to change much with age. Likewise, we see little variation in the ideal number of children among women. Whereas the ideal number of children increases slightly across the life course among men, the number decreases slightly among women. When they are in their twenties, women have an ideal number of children that is slightly higher than that of men. This number increases to 2.3 when they are in their thirties, and then declines to 2.1 when they are in their forties. However, the fluctuations are modest and are within the range of the statistical error margin of $95 \%$. We conclude that fertility ideals at an aggregate level of the cohorts under study are relatively stable, even though some variation exists.

In a second step, we examine the within variation of fertility ideals. Table 11.2 reports the between and within variation for fertility preferences by gender and 
Table 11.1 Composition of the sample by person-years, column per cent

\begin{tabular}{|c|c|c|}
\hline & Men & Women \\
\hline Ideal number of children (Mean \& std. error) & $2.17(0.07)$ & $2.23(0.06)$ \\
\hline $\begin{array}{l}\text { Satisfaction with financial situation of household } \\
\text { (Mean \& std. error) }\end{array}$ & $6.57(0.02)$ & $6.45(0.02)$ \\
\hline \multicolumn{3}{|l|}{ Age } \\
\hline $14-19$ & $26 \%$ & $24 \%$ \\
\hline $20-29$ & $33 \%$ & $31 \%$ \\
\hline $30-39$ & $31 \%$ & $35 \%$ \\
\hline $40-42$ & $10 \%$ & $11 \%$ \\
\hline \multicolumn{3}{|l|}{ Region } \\
\hline West & $72 \%$ & $73 \%$ \\
\hline East & $28 \%$ & $27 \%$ \\
\hline \multicolumn{3}{|l|}{ Country of birth } \\
\hline Born in Germany & $91 \%$ & $89 \%$ \\
\hline Not born in Germany & $9 \%$ & $11 \%$ \\
\hline \multicolumn{3}{|l|}{ Number of children } \\
\hline Childless & $68 \%$ & $53 \%$ \\
\hline 1 child & $13 \%$ & $18 \%$ \\
\hline 2 children & $14 \%$ & $20 \%$ \\
\hline 3 and more children & $6 \%$ & $9 \%$ \\
\hline \multicolumn{3}{|l|}{ Partnership status } \\
\hline No Partner & $41 \%$ & $29 \%$ \\
\hline Partner & $59 \%$ & $71 \%$ \\
\hline \multicolumn{3}{|l|}{ Level of education } \\
\hline Low & $40 \%$ & $37 \%$ \\
\hline Medium & $39 \%$ & $42 \%$ \\
\hline High & $21 \%$ & $21 \%$ \\
\hline Missing & $0 \%$ & $0 \%$ \\
\hline \multicolumn{3}{|l|}{ Employment status } \\
\hline In education & $3 \%$ & $3 \%$ \\
\hline Employed full-time & $85 \%$ & $56 \%$ \\
\hline Employed part-time & $3 \%$ & $22 \%$ \\
\hline Unemployed & $6 \%$ & $5 \%$ \\
\hline Other & $3 \%$ & $15 \%$ \\
\hline Person years & 24,586 & 27,067 \\
\hline Subjects & 6,628 & 7,017 \\
\hline
\end{tabular}

Source: German Family Panel (pairfam) wave 1-6, Release 6.0

region. The most important finding displayed in this table is that variation between individuals is much larger than variation within an individual. But there is still substantial within variation, which suggests that a considerable fraction of the population under study change their fertility ideals over survey waves. While men and women do not seem to differ, some differences are found between eastern and western Germany. On average, fertility ideals are higher in western than in eastern Germany, and are more stable in eastern than in western Germany. 


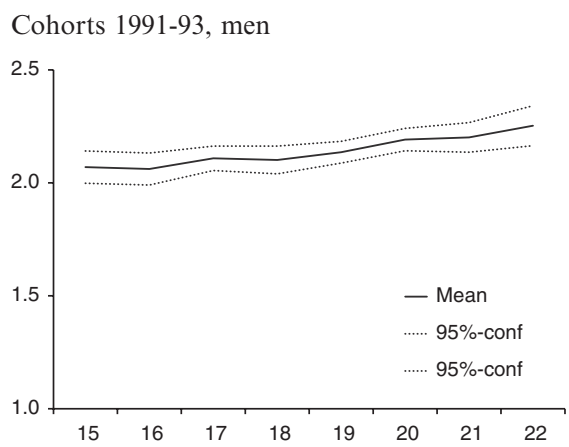

Cohorts 1991-93, Women

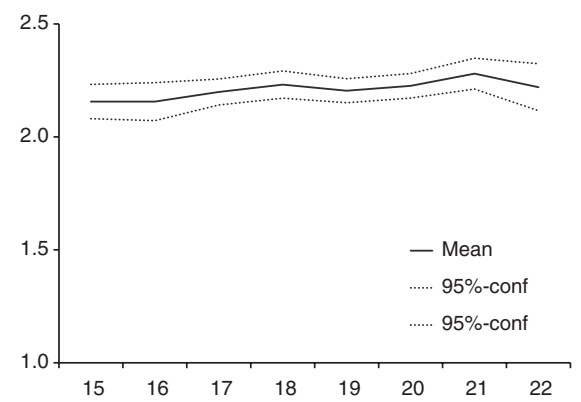

Cohorts 1981-83, men

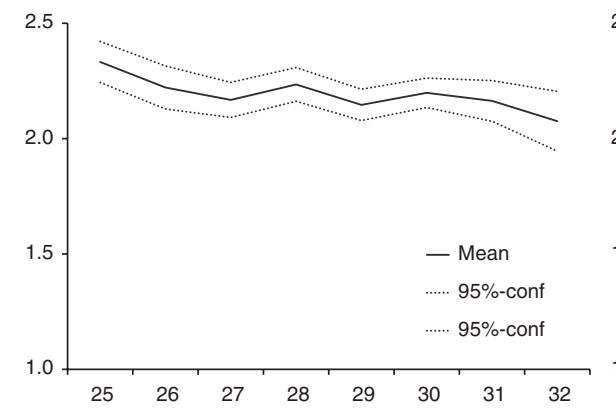

Cohorts 1981-83, Women

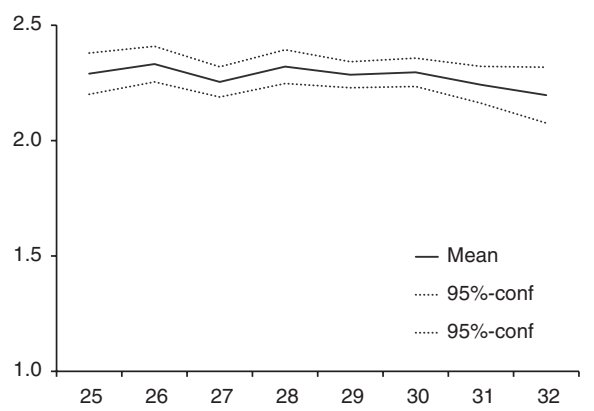

Cohorts 1971-73, men
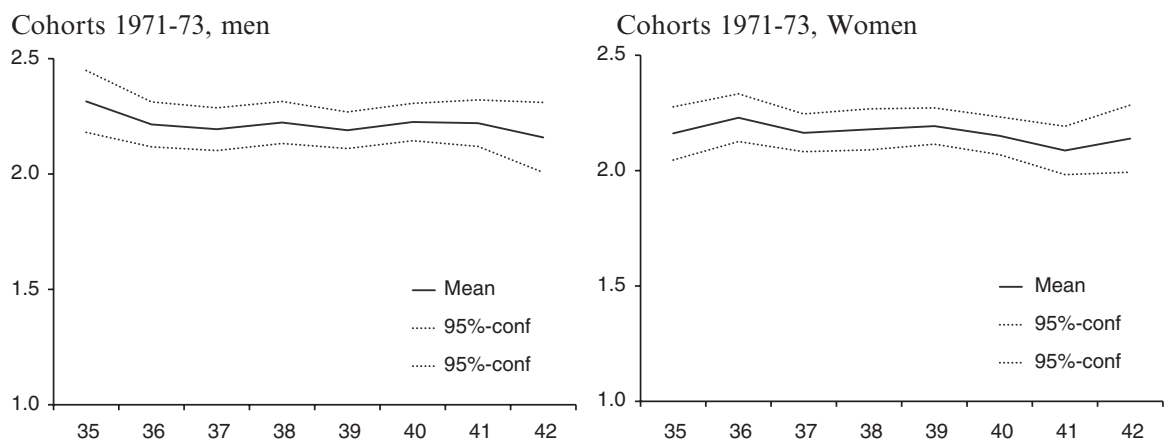

Fig. 11.2 Ideal family size by age, cohort and sex, mean and $95 \%$ confidence level. (Source: German Family Panel (pairfam) wave 1-6, Release 6.0, weighted estimates)

\subsection{Multivariate Results}

Table 11.3 displays the results from the OLS models, separately for men and women. We start by discussing our findings on partnership status and economic conditions. With respect to partnership status, we find that men with a partner have a significantly higher fertility ideal than men without a partner. This association does not hold for women, however. Respondents who are (still) in education have higher fertility preferences than those in full-time employment. This finding might 
Table 11.2 Within and between variation of fertility ideals

\begin{tabular}{|c|c|c|c|c|c|}
\hline & \multirow[t]{2}{*}{ Mean } & \multicolumn{3}{|l|}{ St. Dev. } & \multirow[t]{2}{*}{ Person-years } \\
\hline & & Overall & Between & Within & \\
\hline All & 2.20 & 0.96 & 0.87 & 0.49 & 51,653 \\
\hline \multicolumn{6}{|l|}{ Gender } \\
\hline Men & 2.16 & 0.93 & 0.85 & 0.50 & 24,586 \\
\hline Women & 2.23 & 0.98 & 0.89 & 0.49 & 27,067 \\
\hline \multicolumn{6}{|l|}{ Region } \\
\hline West Germany & 2.24 & 0.97 & 0.89 & 0.51 & 37,230 \\
\hline East Germany & 2.08 & 0.90 & 0.82 & 0.45 & 14,423 \\
\hline
\end{tabular}

Source: German Family Panel (pairfam) wave 1-6, Release 6.0

be a reflection of the respondents' life course stage, rather than of their economic situation. Unemployment does not seem to be associated with lower fertility preferences, as we do not find statistically significant differences in the preferences of respondents depending on whether they are employed. We also find that fertility preferences do not appear to be associated with satisfaction with the household's financial situation. In addition, we find that the level of education matters for fertility preferences: The respondents who are highly educated are more likely to prefer having a large family than their less educated counterparts. This result for women is particularly surprising, as we know from other studies that highly educated women in Germany are more likely than other women to remain childless (see Kreyenfeld and Konietzka in this volume).

When we look at the effect of age, we find that fertility preferences decline significantly across the life course. On average, men's fertility preferences at age 40-42 are by 0.36 units lower than at ages 14-19. Among women, there is even a reduction by 0.59 units, which may be indicative of a stronger awareness of biological constraints. Please note that this stands in some contrast to the descriptive findings that did not show a strong age-gradient. Thus, the control variables seem to be suppressors in the relationship between age and fertility preferences. The ideal number of children is lower among eastern than western Germans. This result is consistent with previous descriptive findings indicating that most eastern Germans prefer to have a smaller family (Buhr and Huinink 2010). In line with previous studies on the fertility behaviour of foreigners and migrants in Germany, we find that ideal number of children is higher among foreign-born than native-born respondents (Helfferich et al. 2011; Schmid and Kohls 2011). The number of children also has a very strong effect on preferred fertility, as men and women who already have three or more children have a higher ideal number of children than other respondents. This finding is not surprising. First, we can assume that respondents who are more family-oriented and have a large number of children at the time of the interview will also report that they have a high "fertility ideal". Second, as their number of children increases, respondents will adjust their ideal to their family situation. These two mechanisms cannot be disentangled in the OLS-regression, but they can be addressed in the fixed-effects models below. Taken together, the findings from the 
Table 11.3 Results from OLS regression, dependent variable: fertility ideals, beta coefficient and standard errors, (standard errors are adjusted for clustering in id)

\begin{tabular}{|c|c|c|c|c|c|c|}
\hline & \multicolumn{2}{|l|}{ Men } & & \multicolumn{2}{|l|}{ Women } & \\
\hline & b & $\begin{array}{l}\text { Std. } \\
\text { err. }\end{array}$ & & $b$ & $\begin{array}{l}\text { Std. } \\
\text { err. }\end{array}$ & \\
\hline \multicolumn{7}{|l|}{ Age } \\
\hline $14-19$ & 1 & & & 1 & & \\
\hline $20-29$ & 0.02 & 0.02 & & -0.06 & 0.02 & ** \\
\hline $30-39$ & -0.20 & 0.03 & $* * *$ & -0.42 & 0.04 & $* * *$ \\
\hline $40-42$ & -0.36 & 0.04 & $* * *$ & -0.59 & 0.04 & $* * *$ \\
\hline \multicolumn{7}{|l|}{ Region } \\
\hline Western Germany & 1 & & & 1 & & \\
\hline Eastern Germany & -0.13 & 0.02 & $* * *$ & -0.14 & 0.02 & $* * *$ \\
\hline \multicolumn{7}{|l|}{ Migration status } \\
\hline Born in Germany & 1 & & & 1 & & \\
\hline Born in other country & 0.19 & 0.04 & $* * *$ & 0.08 & 0.04 & $* *$ \\
\hline \multicolumn{7}{|l|}{ Number of children } \\
\hline Childless & -0.17 & 0.03 & $* * *$ & -0.25 & 0.03 & $* * *$ \\
\hline 1 child & 1 & & & 1 & & \\
\hline 2 children & 0.32 & 0.03 & $* * *$ & 0.39 & 0.03 & $* * *$ \\
\hline 3 or more children & 1.35 & 0.05 & $* * *$ & 1.33 & 0.05 & $* * *$ \\
\hline \multicolumn{7}{|l|}{ Partnership status } \\
\hline No Partner & 1 & & & 1 & & \\
\hline Partner & 0.04 & 0.02 & $* * *$ & -0.02 & 0.02 & \\
\hline \multicolumn{7}{|l|}{ Level of education } \\
\hline Low & -0.14 & 0.03 & $* * *$ & -0.11 & 0.03 & $* * *$ \\
\hline Medium & 1 & & & 1 & & \\
\hline High & 0.05 & 0.03 & & 0.10 & 0.03 & $* * *$ \\
\hline Other/Missing & 0.86 & 0.05 & $* * *$ & - & & \\
\hline \multicolumn{7}{|l|}{ Employment status } \\
\hline In education & 0.15 & 0.07 & $* *$ & 0.16 & 0.05 & **** \\
\hline Employed full-time & 1 & & & 1 & & \\
\hline Employed part-time & 0.03 & 0.05 & & 0.01 & 0.03 & \\
\hline Unemployed & 0.01 & 0.07 & & -0.05 & 0.04 & \\
\hline Other/Missing & 0.07 & 0.07 & & 0.02 & 0.03 & \\
\hline $\begin{array}{l}\text { Satisfaction with financial situation of } \\
\text { household }\end{array}$ & 0.002 & 0.00 & & 0.007 & 0.00 & $*$ \\
\hline Constant & 2.24 & 0.07 & $* * *$ & 2.40 & 0.05 & $* * *$ \\
\hline R squared & 0.17 & & & 0.19 & & \\
\hline N (Person-years) & 24,586 & & & 27,067 & & \\
\hline
\end{tabular}

Source: German Family Panel (pairfam) wave 1-6, Release 6.0

Notes: $* * * \mathrm{p}<0.01, * * \mathrm{p}<0.05, * \mathrm{p}<0.1$ 
OLS-regression reveal only weak associations between current living conditions, partnership status, and fertility ideals.

Next, we turn to the results from the fixed-effects model (Table 11.4). Fixed-effects modelling accounts for unobserved heterogeneity by "de-meaning" the data. Because fixed-effects analysis only draws on the within variation of individuals, the power of the model is lower than that of OLS-regressions. It is therefore more difficult to generate significant results with fixed-effects regressions than with OLS-modelling. However, even if we allowed for a very generous level of significance, the coefficients for partnership status or economic conditions do not come close to having an acceptable level of statistical significance. From this analysis, we conclude that neither

Table 11.4 Results from fixed-effects model, dependent variable: fertility ideals, beta coefficient and standard errors

\begin{tabular}{l|l|l|l|l|l|l}
\hline & \multicolumn{2}{|l|}{ Men } & \multicolumn{2}{l|}{ Women } & \\
\hline & $\mathrm{b}$ & $\begin{array}{l}\text { Std. } \\
\text { err. }\end{array}$ & $\mathrm{b}$ & $\begin{array}{l}\text { Std. } \\
\text { err. }\end{array}$ & \\
\hline
\end{tabular}

Age

\begin{tabular}{l|l|l|l|l|l|l}
\hline $14-19$ & 1 & & & 1 & & \\
\hline $20-29$ & 0.02 & 0.02 & & -0.01 & 0.02 & $* * *$ \\
\hline $30-39$ & 0.01 & 0.02 & & -0.06 & 0.02 & $* * *$ \\
\hline $40-42$ & -0.02 & 0.03 & & -0.13 & 0.03 & $* * *$ \\
\hline
\end{tabular}

\section{Number of children}

\begin{tabular}{l|l|l|l|l|l|l}
\hline Childless & -0.09 & 0.03 & $* *$ & -0.09 & 0.04 & $* * *$ \\
\hline 1 child & 1 & & & 1 & & \\
\hline 2 children & 0.19 & 0.04 & $* * *$ & 0.13 & 0.03 & $* * *$ \\
\hline 3 or more children & 0.41 & 0.07 & $* * *$ & 0.48 & 0.06 & $* * *$ \\
\hline Partnership status & 0.02 & 0.02 & & 0.02 & 0.02 & \\
\hline No Partner & 1 & & & 1 & & \\
\hline Partner & \multicolumn{7}{|l|}{}
\end{tabular}

\section{Employment status}

\begin{tabular}{l|l|l|l|l|l|l}
\hline In education & 0.00 & 0.05 & & 0.00 & 0.04 & \\
\hline Employed full-time & -0.04 & 0.03 & & -0.02 & 0.02 & \\
\hline Employed part-time & -0.02 & 0.04 & & 0.01 & 0.03 & \\
\hline Unemployed & 1 & & & 1 & & \\
\hline Other/Missing & -0.02 & 0.04 & & -0.04 & 0.02 & $*$ \\
\hline $\begin{array}{l}\text { Satisfaction with financial situation of } \\
\text { household }\end{array}$ & 0.002 & 0.00 & & 0.002 & 0.00 & \\
\hline Constant & 2.18 & 0.05 & $* * *$ & 2.24 & 0.04 & $* * *$ \\
\hline R square & \multicolumn{7}{|l|}{} & & & & \\
\hline Within & 0.01 & & & 0.01 & & \\
\hline Between & 0.14 & & & 0.19 & & \\
\hline Overvall & 0.11 & & & 0.15 & & \\
\hline N (Person-years) & 24,586 & & & 27,067 & & \\
\hline
\end{tabular}

Source: German Family Panel (pairfam) wave 1-6, Release 6.0

Notes: $* * * \mathrm{p}<0.01, * * \mathrm{p}<0.05, * \mathrm{p}<0.1$ 
changes in partnership status nor changes in economic conditions impact fertility preferences. What does seem to matter, however, is the number of children a respondent has. Since fixed-effects models exploit the within variation, the coefficients tell us that the respondents whose number of children changed across the panel waves also changed their fertility preferences. As their number of children increased, the respondents adjusted their preferences upwards. This finding is fully in line with the argument by Miller and Pasta (1995) that the birth of a first child in particular increases the motivation for further childbearing. This may be attributable to a justification mechanism whereby each child born will be treated as if he or she was intended. Another potential explanation is that the respondents became more knowledgeable about the advantages and disadvantages of parenthood after the birth of a child, and that those who experienced parenthood as an overwhelmingly positive event came to associate having a larger number of children with more gains, and thus increased their fertility ideals. Interestingly, in the fixed-effects model the negative impact of age on fertility ideals disappears among men, and is found among women only. Among women, age has a negative effect on fertility preferences. This suggests that as women age they adjust their fertility ideals downwards, most likely because they become aware that it is unlikely that they will be able to achieve their initial goals.

\subsection{Conclusion}

In this paper, we investigated the evolution of fertility preferences in Germany across six waves of panel data. Preferences were measured using the following question: "Under ideal circumstances, how many children would you like to have?" We find that, on average, men and women prefer to have 2.2 children. The average number of "preferred children" slightly declines with increasing age. We also find that there is some variation in fertility ideals within individuals across time. We examined if these individual-level variations in fertility ideals would be related to changes in the respondent's partnership status or economic or employment situation. In a pooled OLS-regression, we show that satisfaction with the economic situation is positively related with fertility preferences among women, while having a partner has a positive impact on fertility ideals among men. However, the fixedeffects model that accounts for individual time-invariant heterogeneity did not confirm these findings. A major result of our analysis is therefore that fertility preferences, measured as "personal ideals," are relatively unaffected by short-term changes in life circumstances. These results support the findings of previous studies that showed that economic conditions do not significantly affect fertility preferences (e.g., Heiland et al. 2008; Iacovou and Tavares 2011). However, they are at odds with the findings of studies that found that partnership dissolution affects the desired number of children (Gray et al. 2013). The discrepancies between these findings may be explained by how fertility preferences are operationalised in our study. We used "fertility ideals" as a dependent variable. In the interview, the respondents were asked to report their desired number of children "under ideal 
circumstances." Because the respondents were asked to disregard their current circumstances, they may not have factored in their current employment situation or their partnership status.

While our findings indicate that partnership and economic conditions do not alter fertility ideals, they also show that an increase in the number of children in the respondent's family is associated with an upward adjustment of fertility preferences. Among women, increasing age is associated with a downward adjustment. This in turn suggests that individual-level variation in fertility ideals is largely explained by factors that are closely linked to goal achievement, such as the number of children already born and the woman's age. These findings are consistent with psychological theories of goal adjustment: i.e., that individuals will revise their fertility preferences if they perceive that it is unlikely that their initial goal will be realised, and that they will also change their preferences if they have more children than they had initially considered ideal. In sum, fertility ideals seem to be unaffected by short-term changes in the respondents' partnership status and employment situation, but they are sensitive to the achievement of long-term goals. In order to gain a more comprehensive understanding of the volatility of fertility ideals, we therefore need to have data that capture a long-term perspective. Only by using a sufficiently long-term panel will we be able to unravel the process through which people adjust their preferences based on their life course experiences. We were fortunate to have had access to 5 years of panel data. However, even this time horizon is short, as it captures only a snap-shot of the life course of an individual. For example, we were unable to produce any statistically significant results on the effects of union dissolution or unemployment on fertility preferences. We were also unable to explore whether previous disruptions in an individual's union or employment career affected the evolution of his or her fertility preferences. Unemployment or the lack of a suitable partner may not have an immediate impact on fertility preferences, but having a long history of economic hardship or complex partnerships may result in a downward or upward adjustment of fertility ideals at later ages. A direction for future research would be a systematic study of the long-term impact of the economic and partnership situations of individuals on their fertility preferences based on different concepts, such as personal ideals, desires, and intentions.

\section{Literature}

Ajzen, I. (1991). The theory of planned behavior. Organizational Behavior and Human Decision Processes, 50, 179-211.

Allison, P. D. (2009). Fixed effects regression models. Thousand Oaks: Sage.

Andreß, H.-J., Golsch, K., \& Schmidt, A. (2013). Applied panel data analysis for economic and social surveys. New York: Springer.

Balbo, N., \& Mills, M. (2011). The effects of social capital and social pressure on the intention to have a second or third child in France, Germany, and Bulgaria, 2004-05. Population Studies, 65, 335-351. 
Bernardi, L., Mynarska, M., \& Rossier, C. (2015). Uncertain, changing and situated fertility intentions. In D. Philipov, A. C. Liefbroer, \& J. Klobas (Eds.), Reproductive decision-making in a macro-micro perspective (pp. 113-139). Dordrecht: Springer.

Berrington, A., \& Pattaro, S. (2014). Educational differences in fertility desires, intentions and behaviour: A life course perspective. Advances in Life Course Research, 21, 10-27.

Billari, F. C., Philipov, D., \& Testa, M. R. (2009). Attitudes, norms and perceived behavioural control: Explaining fertility intentions in Bulgaria. European Journal of Population/Revue européenne de Démographie, 25, 439-465.

Brüderl, J., \& Ludwig, V. (2014). Fixed-effects panel regression. In H. Best \& C. Wolf (Eds.), SAGE handbook of regression analysis and causal inference (pp. 327-359). London: Sage.

Brüderl, J., Hajek, K., Herzig, M., Huyer-May, B., Lenke, R., Müller, B., Schüzte, P., \& Schumann, N. (2015). Pairfam data manual, Release 6.0. München: Universität München.

Bühler, C. (2012). How to measure preferred family size? A discussion of different approaches. Leibniz Universität Hannover: Unpublished manuscript.

Buhr, P., \& Huinink, J. (2010). Kinderwünsche von Männern und Frauen. In J. Goldstein, M. Kreyenfeld, J. Huinink, D. Konietzka, \& H. Trappe (Eds.), Familie und Partnerschaft in Ost- und Westdeutschland - Ergebnisse im Rahmen des Projektes Demographic differences in life course dynamics in eastern and western Germany (pp. 18-19). Rostock: Max-PlanckInstitut für demografische Forschung.

Buhr, P., \& Kuhnt, A.-K. (2012). Die kurzfristige Stabilität des Kinderwunsches von Kinderlosen in Ost-und Westdeutschland: eine Analyse mit den ersten beiden Wellen des deutschen Beziehungs-und Familienpanels. Zeitschrift für Familienforschung, Sonderheft, 2012, 275-297.

Dommermuth, L., Klobas, J., \& Lappegård, T. (2011). Now or later? The theory of planned behavior and timing of fertility intentions. Advances in Life Course Research, 16, 42-53.

Fishbein, M., \& Ajzen, I. (2010). Predicting and changing behavior: The reasoned action approach. New York: Taylor \& Francis.

Goldstein, J., Lutz, W., \& Testa, M. R. (2003). The emergence of sub-replacement family size ideals in Europe. Population Research and Policy Review, 22, 479-496.

Gray, E., Evans, A., \& Reimondos, A. (2013). Childbearing desires of childless men and women: When are goals adjusted? Advances in Life Course Research, 18, 141-149.

Hakim, C. (2003). A new approach to explaining fertility patterns: Preference theory. Population and Development Review, 29, 349-374.

Hayford, S. R. (2009). The evolution of fertility expectations over the life course. Demography, 46, 765-783.

Heiland, F., Prskawetz, A., \& Sanderson, W. C. (2008). Are individuals' desired family sizes stable? Evidence from West German panel data. European Journal of Population/Revue européenne de Démographie, 24, 129-156.

Helfferich, C., Klindworth, H., \& Kruse, J. (2011). frauen leben - Familienplanung und Migration im Lebenslauf. Köln: Bundeszentrale für gesundheitliche Aufklärung.

Huinink, J., \& Feldhaus, M. (2009). Family research from the life course perspective. International Sociology, 24, 299-324.

Huinink, J., Brüderl, J., Nauck, B., Walper, S., Castiglioni, L., \& Feldhaus, M. (2011). Panel analysis of intimate relationships and family dynamics (pairfam): Conceptual framework and design. Zeitschrift für Familienforschung, 23, 77-101.

Iacovou, M., \& Tavares, L. P. (2011). Yearning, learning, and conceding: Reasons men and women change their childbearing intentions. Population and Development Review, 37, 89-123.

Inglehart, R. (1977). The silent revolution. Princeton: Princeton University Press.

Kapitány, B., \& Spéder, Z. (2013). Realization, postponement or abandonment of childbearing intentions in four European countries. Population, 67, 599-629.

Keim, S., Klärner, A., \& Bernardi, L. (2009). Qualifying social influence on fertility intentions composition, structure and meaning of fertility-relevant social networks in Western Germany. Current Sociology, 57, 888-907. 
Klobas, J. E., \& Ajzen, I. (2015). Making the decision to have a child. In D. Philipov, A. C. Liefbroer, \& J. E. Klobas (Eds.), Reproductive decision-making in a macro-micro environment (pp. 41-78). Dordrecht: Springer.

Kreyenfeld, M., Huinink, J., Trappe, H., \& Walke, R. (2012). DemoDiff: A dataset for the study of family change in eastern (and western) Germany. Schmollers Jahrbuch, 132, 653-660.

Kuhnt, A.-K. (2013). Ja, nein, vielleicht? Der Einfluss der Partnerschaftsqualität auf die Übereinstimmung der Elternschaftsabsichten von Paaren. Zeitschrift für Familienforschung, $25,365-388$.

Kuhnt, A.-K., \& Trappe, H. (2013). Easier said than done: Childbearing intentions and their realization in a short term perspective (MPIDR working paper WP 2013-018: Max Planck Institute for Demographic Research). Rostock: Rostock Max-Planck-Institut für demografische Forschung.

Lesthaeghe, R., \& Moors, G. (2002). Life course transitions and value orientations: selection and adaptation. In R. Lesthaeghe (Ed.), Meaning and choice: Value orientations and life course decisions (pp. 1-44). Brussels: CBGS.

Liefbroer, A. C. (2009). Changes in family size intentions across young adulthood: A life-course perspective. European Journal of Population/Revue européenne de Démographie, 25, 363-386.

Lutz, K., Buhr, P., \& Boehnke, M. (2013). Die Bedeutung der Erfahrungen mit dem ersten Kind für die Intention zur Familienerweiterung. Zeitschrift für Soziologie der Erziehung und Sozialisation, 33, 169-186.

Marbach, J. H., \& Tölke, A. (2013). Frauen, Männer und Familie. Lebensorientierung, Kinderwunsch und Vaterrolle. In D. Konietzka \& M. Kreyenfeld (Eds.), Ein Leben ohne Kinder: Ausmaß, Strukturen und Ursachen von Kinderlosigkeit (pp. 281-310). Wiesbaden: Springer VS.

Mayer, K. U. (2004). Whose lives? How history, societies and institutions define and shape life courses. Research in Human Development, 1, 161-187.

Miller, W. B. (1994). Childbearing motivations, desires, and intentions: A theoretical framework. Genetic, Social, and General Psychology Monographs, 120, 223-258.

Miller, W. B. (2011). Differences between fertility desires and intentions: Implications for theory, research and policy. Vienna Yearbook of Population Research, 9, 75-98.

Miller, W. B., \& Pasta, D. J. (1995). How does childbearing affect fertility motivations and desires? Social Biology, 42, 185-198.

Morgan, S. P. (1982). Parity-specific fertility intentions and uncertainty: The United States, 1970 to 1976. Demography, 19, 315-334.

Müller, B., \& Castiglioni, L. (2015). Attrition im Beziehungs- und Familienpanel pairfam. In J. Schupp \& C. Wolf (Eds.), Nonresponse Bias (pp. 383-408). Wiesbaden: Springer.

Ní Bhrolcháin, M., \& Beaujouan, É. (2011). Uncertainty in fertility intentions in Britain. Vienna Yearbook of Population Research, 9, 99-129.

Ní Bhrolcháin, M., Beaujouan, E., \& Berrington, A. (2010). Stability and change in fertility intentions in Britain, 1991-2007. Population Trends, 141, 13-35.

Philipov, D., Spéder, Z., \& Billari, F. C. (2006). Soon, later, or ever? The impact of anomie and social capital on fertility intentions in Bulgaria (2002) and Hungary (2001). Population Studies, 60, 289-308.

Puur, A., Oláh, L. S., Tazi-Preve, M. I., \& Dorbritz, J. (2008). Men's childbearing desires and views of the male role in Europe at the dawn of the 21st century. Demographic Research, 19, $1883-1912$.

Quesnel-Vallée, A., \& Morgan, S. P. (2004). Missing the target? Correspondence of fertility intentions and behavior in the US. Population Research and Policy Review, 22, 497-525.

Régnier-Loilier, A. (2006). Influence of own sibship size on the number of children desired at various times of life: The Case of France. Population (english edition), 6, 165-194.

Régnier-Loilier, A., Vignoli, D., \& Dutreuilh, C. (2011). Fertility intentions and obstacles to their realization in France and Italy. Population, 66, 361-389. 
Rost, H. (2005). Kinder - Wunsch und Wirklichkeit. Zeitschrift für Familienforschung, 17, 8-20.

Ruckdeschel, K. (2007). Der Kinderwunsch von Kinderlosen. Zeitschrift für Familienforschung, $19,210-230$.

Schmid, S., \& Kohls, M. (2011). Generatives Verhalten und Migration - Eine Bestandsaufnahme des generativen Verhaltens von Migrantinnen in Deutschland. Nürnberg: Bundesamt für Migration und Flüchtlinge.

Schoen, R., Astone, N. M., Kim, Y. J., Nathanson, C. A., \& Fields, J. M. (1999). Do fertility intentions affect fertility behavior? Journal of Marriage and the Family, 61, 790-799.

Spéder, Z., \& Kapitány, B. (2009). How are time-dependent childbearing intentions realized? Realization, postponement, abandonment, bringing forward. European Journal of Population/ Revue européenne de Démographie, 25, 503-523.

Spéder, Z., \& Kapitány, B. (2015). Influences on the link between fertility intentions and behavioural outcomes. In D. Philipov, A. C. Liefbroer, \& J. Klobas (Eds.), Reproductive decisionmaking in a macro-micro perspective (pp. 79-112). Dordrecht: Springer.

Testa, M. R. (2007). Childbearing preferences and family issues in Europe: Evidence from the Eurobarometer 2006 survey. Vienna Yearbook of Population Research, 5, 353-377.

Testa, M. R., \& Basten, S. (2014). Certainty of meeting fertility intentions declines in Europe during the 'Great Recession'. Demographic Research, 31, 687-734.

Thomson, E. (1997). Couple childbearing desires, intentions, and births. Demography, 34, 343-354.

Thomson, E. (2001). Family size preferences. In N. J. Smelser \& P. B. Baltes (Eds.), International encyclopedia of the social \& behavioral sciences (pp. 5347-5350). Oxford: Pergamon.

Thomson, E., \& Hoem, J. M. (1998). Couple childbearing plans and births in Sweden. Demography, $35,315-322$.

Toulemon, L., \& Testa, M. R. (2005). Fertility intentions and actual fertility: A complex relationship. Population and Societies, 415, 1-4.

Vignoli, D., Rinesi, F., \& Mussino, E. (2013). A home to plan the first child? Fertility intentions and housing conditions in Italy. Population, Space and Place, 19, 60-71.

Open Access This chapter is distributed under the terms of the Creative Commons Attribution 4.0 International License (http://creativecommons.org/licenses/by/4.0/), which permits use, duplication, adaptation, distribution and reproduction in any medium or format, as long as you give appropriate credit to the original author(s) and the source, provide a link to the Creative Commons license and indicate if changes were made.

The images or other third party material in this chapter are included in the work's Creative Commons license, unless indicated otherwise in the credit line; if such material is not included in the work's Creative Commons license and the respective action is not permitted by statutory regulation, users will need to obtain permission from the license holder to duplicate, adapt or reproduce the material.

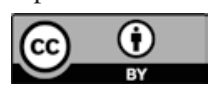

